\title{
Protracted crustal and mantle melting during the late stages of the Variscan orogeny: a case study in the Paleozoic basement of the external western Alps
}

\author{
JEAN-BAPTISTE JACOB ${ }^{1}$, KÉVIN FRÉVILLE ${ }^{2}$, EMILIE \\ JANOTS $^{3}$, MARC POUJOL ${ }^{4}$, STÉPHANE GUILLOT $^{5}$, \\ PIERRE TRAP $^{2}$, JÉRÉMIE MELLETON ${ }^{6}$ AND MICHEL \\ FAURE $^{7}$
}

${ }^{1}$ Université Grenoble-Alpes

${ }^{2}$ Université de Franche-Comté

${ }^{3}$ ISTerre-UGA

${ }^{4}$ Géosciences Rennes

${ }^{5} \mathrm{CNRS}$

${ }^{6} \mathrm{BRGM}$

${ }^{7}$ Université d'Orléans

Presenting Author: jean-baptiste.jacob@univ-grenoble-alpes.fr

The Variscan Belt of Europe is a typical example of a composite magmatic province, in which large volumes of granitoids were generated from various crustal and mantle sources and by several processes during the syn to late collisional evolution. In such a complex setting, many questions arise regarding magmatic and heat sources and melting mechanisms.

We present a case study focused on the Variscan basement of the external Western Alps, in the massifs of Belledonne and Pelvoux. In this area, three distinct magmatic suites have been recognized: (i) $\mathrm{Mg}-\mathrm{K}$-rich subalkaline granitoids ( $\mathrm{Mg}-\mathrm{K}$ group) rich in mafic enclaves (MMEs); (ii) ferroan medium/high-K granitoids (Fe-K), almost devoid of MMEs; (iii) an ultrapotassic suite consisting of (quartz)-syenite plutonic bodies and lamprophyres. We exploited a large dataset of whole rock geochemical analyses and single grain zircon $\mathrm{U}-\mathrm{Pb}$ dates obtained on these three suites to constrain their timing of emplacement, evaluate the relative contribution of these series over time, and identify possible magmatic sources.

Distribution analysis of zircon U-Pb dates reveals that emplacement of the $\mathrm{Mg}-\mathrm{K}$ granitoids occurred over a protracted period from ca. $350 \mathrm{Ma}$ to $295 \mathrm{Ma}$, with two dominant production peaks near $340 \mathrm{Ma}$ and $305 \mathrm{Ma}$. In contrast, the Fe-K granitoids mostly emplaced during a short-lived event at ca. 305$295 \mathrm{Ma}$. Two dated ultrapotassic granitoids yielded concordant ages at ca. $325 \mathrm{Ma}$. Fe-K and $\mathrm{Mg}-\mathrm{K}$ granitoids contain various loads of inherited pre-Carboniferous zircons, suggesting significant crustal contribution while the ultrapotassic granitoids are devoid of inheritance.

Ultrapotassic rocks are interpreted to derive from LILE-rich metasomatized sub-continental mantle. Both $\mathrm{Mg}-\mathrm{K}$ and $\mathrm{Fe}-\mathrm{K}$ suites are subalkaline and moderately peraluminous, with remarkable scarcity of highly peraluminous compositions. This likely reflects the Al-poor composition of the crustal pile, which contains a mix of mafic and felsic igneous rocks and volcanosediments, and is thus more prone to generate "I type" than "S types" granitoids. High $\mathrm{Mg} \#$ in the $\mathrm{Mg}-\mathrm{K}$ granitoids suggests incorporation of a mantle component, either by assimilation of the mafic enclaves or by mixing of crustal melts with ultrapotassic fractionates. Evolution toward $\mathrm{Fe}-\mathrm{K}$ granitoids is interpreted to indicate increasing contribution of crustal melts over time. 